erkennt man leicht mittelst Barytwassers, welches einen röthlichen bis violetten Niederschlag giebt. Die dialursauren Salze sind trocken sehr beständig. Die Formel ist nach Liebig, Wöhler und Gregory $=\mathrm{C}^{8} \cdot \mathrm{N}^{2} \mathrm{H}^{3} \mathrm{O}^{7}+\mathrm{HO}$.

Saures thionursaures Ammoniak erhält man, wenn die Lösung des neutralen, zweibasischen, thionursauren Ammoniaks genau mit 1 Aequiv. Salzsäure versetzt und vorsichtig concentrirt wird. Beim Erkalten scheidet sich das Salz in Krusten prismatischer Krystalle ab.

Alloxanschweflige Säure. Eine Lösung von Alloxan in schwefliger Säure setzt nach Liebig und Wöhler beim langs. Verdamplen grosse saure tafelförmige Krystalle $a b$, welche mit Ammoniak ein eigerthümliches gallertartiges Salz geben. Löst man Alloxan in möglichst wenig kaltem Wasser, versetzt die liosung mit einem geringen Ueberschuss einer gesätligten wässerigen Aullösung von schwefliger Säure und fügt dann Aelzkalilauge bis zur schwachen alkalischen Reaction zu, so setzen sich theils sogleich, theils beim Stehen farblose durchsichtige, harte gläzende Krystalle ab, die man leicht umkrystallisiren kann. Die Analyse des Salzes zeigt, dass es eine Säure enthält, die aus 1 Atom Alloxan und 2 Atomen schwefliger Säure besteht; es ist bis jetzt noch nicht gelungen, diese, wahrscheinlich einbasische Säure zu isoliren; vielleicht sind die tafelförmigen Krystalle von Liebig und Wöhler diese Säure in freiem Zustande.

Alloxansäure. Wenn man eine kalte Lösung reinen Alloxantins in destillirtem Wasser längere Zeit stehen lässt, so wird sie allmälig saurer und giebt mit Barytwasser endlich einen weissen Niederschlag. Dampft man ab, so erhält man in Wasser und Alkohol Jösliche Krystalle von den Eigenschaften der Alloxansäure. (Gregory in London. Edinb. u. Dubl. philos. Magaz. 1844. March p. 186. - Pharm. Centralbl. 1844. Nr. 16.) B.

\title{
Constitution der Galle.
}

In einer interessanten Arbeit über die Galle haben Theyer und Schlosser das Heer der bis jetzt aus der Galle dargestellten und mit verschiedenen Namen belegten Körper auf eine geringere Anzahl zurïckgefuhrt, und geht aus diesen mit dem schönsten Erfolge gekrönten Untersuchungen hervor, dass Then ard's Picromel, Kemp's Gallensäure, Choleinsäure, Bilifellinsäure, auch Gmelin's Gallenzucker und das Bilin von Berzelius, insofern man sie als alkalifrei annimmt, immer ein und derselbe elek- 
tronegative Körper ist, der die Galle constituirt, und nur seiner leichten Zersetzbarkeit halber so viel Schwierigkeiten in der Darstellung verursacht.

Liebig, unter dessen Aufsicht diese Arbeit ausgeführt wurde, bezeichnet nun den rein dargestellten elektronegativen Körper der Galle mit dem Namen Gallensäure, und ist die Galle, wie schon älterer Ansicht zufolge, wirklich den Hauptbestandtheilen nach, nur eine Verbindung dieser Säure mit Natron.

Folgende von Theyer und Schlosser gegebene Data geben uns genügenden Aufschluss hieriber.

Man reinigt die Galle von Schleim, Farbstoff und Feltsubstanzen, indem dieselbe frisch aus der Blase genommen, durch Leinen colirt, im Wasserbade zur Extractdicke abgedampft, mit gewöhnlichem Alkohol ohne Anwendung von Wärme übergossen, geschüttelt und zu der Auflösung allmälig noch so lange Ailkohol zugesetzt wird, bis keine Trübung mehr entsteht; dann wird die filtrirte Flüssigkeit mit Beinsehwarz 12 Stunden stehen gelassen; das nun farblose Filtrat durch Destillation vom Alliohol bis zur Syrupsconsistenz getrennt, und mit Aether so lange behandelt, bis derselbe beim Verdunsten kein Cholesterin oder Fettsäuren mehr hinterlässt.

Die nun im Wasserbade zur Trockne verdampfte gereinigte Galle stellt ein dem arabischen Gummipulver ähnliches, hygroskopisches, leichtes, bitter hinterher süsslich schmeckendes, im Schlunde kratzendes, höchst schwach alkalisch reagirendes, im Wasser, wasserfrejern und wässerigem Alkohol lösliches, in Aether unlösliches Pulver dar, welches nach dem Verbrennen eine aus kohlensaurem Natron und Chlornatrium bestehende Asche hinterlässt.

Die Analyse der gereinigten Galle gab nach Abzug des Kochsalzgehalts von 3,56 Proc. auf 100 Theile

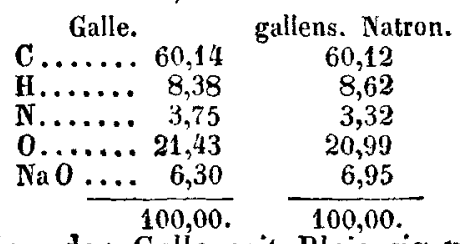

Durch Fällen der Galle mit Bleiessig und Zersetzen des Niederschlages mit kohlensaurem Natron, wurde ein Natronsalz erhalten, welches dieselbe Zusammensetzung, als die gereinigte Galle nach Abzug des Kochsalzgehaltes besass, und sich aus obiger Analyse ergiebt. 
Zur Darstellung der reinen Gallensäure fällt man nach The yer und Sch los s er die gereinigte in Wasser gelöste Galle mit Bleiessig, wäscht den Niederschlag sogleich aus, löst ihn in schwach erwärmtem Alkohol, filtrirt und leitet bis zur völligen Fällung des Bleis Schwefelwasserstoff hindurch; die Flüssigkeit wird darauf eine halbe Stunde schwach erwärmt, weil sonst Schwcfelblei mit durchs Filter geht und das Filtrat einige Zeit hingestellt, wobei sich noch etwas Schwefel abscheidet. - Beim Eindampfen darf die Temperatur nicht über $60^{\circ} \mathrm{C}$ steigen und ist es am zweckmässigsten, die Verdunstung im leeren Raume uber Schwefelsäure vorzunehmen.

Die Säure ist im trocknen, zerriebenen Zustande weiss, dem gepulverten Sandarach ähnlich, hygroskopisch; bei $100^{\circ} \mathrm{C}$ bräunt sie sich nach einiger Zcit, in höherer Temperatur schmilzt sie, bläht sich auf, verbrennt mit starkem Rauche und die Kohle lässt keinen Rückstand. Sie ist in Aether unlöslich, leicht löslich in Alkohol und Wasser; die Auflösung ist farblos, von bitterm, zusammenziehendem Geschmack und stark saurer Reaction. Salzsäure bewirkt einen weissen, harzigen Niederschlag, der nach dem $\mathbf{A b}$ giessen und Abspülen der Salzsäure sich wieder auflöst. Mit Barytwasser gekocht, findet vollkommene Fallung statt unter Entwicklung cines Leimgoruchs und Zersetzung der Säure. - Mit kohlensauren Alkalien längere Zeit in Be. rührung scheidet sich Kohlensäure aus, wahrend sich das Alkali mit der Säure verbindet.

Nach der Analyse besteht dieselbe in $100 \mathrm{Th}$. aus:

$$
\begin{aligned}
& \text { C......6 63,70 63,76 } \\
& \text { H...... } 8,81 \quad 8,50 \\
& \begin{array}{ll}
\mathrm{N} \ldots \ldots & 3,97 \quad 3,45
\end{array} \\
& 0 \ldots \ldots 23,49 \quad \frac{24,29}{100,40}
\end{aligned}
$$

Dieselbe Zusammensetzung berechnet sich aus der Natronverbindung und den von den Verfassern analysirten Bleiverbindungen mit Weglassung der anorganischen Basen. (Annal. der Chem. u. Pharm. Bd.48. p. 77.) Herzog.

\section{Zucker im diabetischen Blute.}

Um den Traubenzucker im Blute mittelst schwefelsauren Kupferoxyds und Kalis zu finden, ist es nach Jon as nothwendig, dass man das Serum, nachdem es sich vom Blutkuchen gesondert, erst im Wasserbade zur Trockne verdampft und den fein gepulverten Ruickstand mit Wasser behandelt und filtrirt. Der Blutkuchen, auf dieselbe Weise bebandelt, giebt ebenfalls durch obiges Reagens 